\title{
ANNOTATION
}

\section{SUTURES IN CATARACT SURGERY}

A RECENT paper in this Journal and subsequent correspondence addressed to the Editor, only some of which has been published, suggest that the collective ophthalmological conscience has been stirred over the use of sutures in cataract surgery, or, to be more precise, over the manner in which such sutures should be removed with least possible physical and psychological trauma to patient and surgeon alike. A joint issue such as this seems to us to call for some form of editorial comment and perhaps to justify one of those annotations which used to be a regular feature of this Journal, but have in recent years fallen into desuetude. Our readers may feel that this resurrection is uncalled for, but we are always ready to extend the editorial neck in a humane cause.

It is interesting to recall that the use of stitches for wound closure in cataract surgery was first advocated in the Royal London Ophthalmic Hospital Reports (a revered ancestor of this Journal) more than 90 years ago by an American, Williams, of Boston. They did not cotton on at the time, but with the increasing trend towards intra-capsular techniques in the 1930s came their renaissance, trailing clouds of eponymous glory which were so widespread that in the end it became almost a mark of distinction-or perhaps of amiable eccentricity-not to have one's own private and peculiar method. Their use is now common, but as regards technique still, almost, quot homines tot sententiae. At the one extreme is the old school, so valuable for its stabilizing influence in any form of human enterprise, which believes that the cataract operation cannot possibly be made too short and too simple and uses no sutures whatever; at the other is the avantgarde which considers it equally impossible to make cataract surgery too complicated or too prolonged and whose operative field is such a cat's cradle of particoloured bits of string as to make the sympathetic onlooker feel that the pallid and perspiring assistant would be properly and more kindly replaced by someone of the calibre of Hornblower's bosun. In the middle of the road, and now of more or less respectable middle age, are those of us of simple type brought up to use one, two, or three sutures, also of simple type, falling between the bravado of the old school and the bravura of the new.

The feeling among the seamsters appears to be that what goes in must come out-hence the pother. Shall we use cotton? Should we use silk? What about evading the issue, using virgin silk (whatever that is), burying it decently and forgetting about it? However, even if we do this last it seems that in many cases the virgin silk is, shall we say charitably, too pure to be tolerated by frail humanity, and quite often even these sutures have to be dug out with even more trouble than usual. It is generally agreed that the removal of corneo-scleral sutures is not entirely free from complications and it may understandably be a trying procedure for a patient looking forward only to going home, especially if it be carried out, as some would advocate, with the full panoply of Bell, Book, and Candle-in other words, sedation, local analgesia and akinesia, and yet another visit to the theatre. 
Inspired no doubt by the recent unequivocal Russian demonstration that what goes up does not necessarily have to come down, many of our correspondents have pointed out that catgut sutures obviate these disadvantages, tranquillize both parties, and are as free from undesirable complications as any of the other materials in common use. They were, of course, advocated as far back as 1944, but at that time were thick and clumsy, and the recently-produced very fine $(000,000)$ gut, plain or chromic, is much more manageable, is of good tensile strength, and can be threaded without difficulty (at least by the Argus-eyed theatre sister) on to any orthodox corneo-scleral needle, or can be obtained already on atraumatic needles. Nature will take care of its disposal, the patient at least will welcome it, and on these two bases the anxious surgeon may rationalize his phobia of dealing with these elusive and often difficult foreign bodies. A stitch is a small thing and perhaps a small matter but-vel de minimis curat chirurgicus.

\section{NOTES \\ Ophthalmological Society of The United Kingdom}

Annual Congress, 1959

The Annual Congress of the Ophthalmological Society of the United Kingdom will be held on April 9, 10, and 11, 1959, under the presidency of Mr. R. C. Davenport, M.B., F.R.C.S., at the Royal Society of Medicine, 1, Wimpole Street, London, W.1.

\section{IRISH Ophthalmological SOCIETY}

Annual Meeting, 1959

The Annual Meeting of the Irish Ophthalmological Society will be held at the Institute of Clinical Science, Belfast on May 14, 15, and 16, 1959, in conjunction with the Section of Ophthalmology, Royal Society of Medicine.

Dr. Joaquin Barraquer of Barcelona will deliver the James Craig Lecture.

\section{South-East Metropolitan Regional Hospital Board Corneo-Plastic Conference, 1959}

A conference will be held on June 26 and 27, 1959, at the Queen Victoria Hospital, East Grinstead, Sussex. There will be a Symposium on "Problems of Tissue Transplantation", and lectures on surgery of the lids, cornea, lacrimal apparatus, and socket. Illustrative cases, operations on closed-circuit television, and scientific exhibits will be shown.

The conference will be strictly limited to sixty members, including places reserved for visitors from abroad and for non-consultant surgeons.

An inaugural dinner will be given to members and their wives on June 26, and excursions have been arranged to Canterbury and Petworth for the ladies.

The registration fee is 5 guineas for consultants and 3 guineas for non-consultants.

Further information may be obtained from the Secretary, Corneo-Plastic Unit, Queen Victoria Hospital, East Grinstead, Sussex. 